\title{
LuftiBus in the school (LUIS): a population-based study on respiratory health in schoolchildren
}

\author{
Mozun Rebeca ${ }^{a b^{*}}$, Kuehni Claudia E. ${ }^{a c^{*}}$, Pedersen Eva S.L.. ${ }^{a}$, Goutaki Myrofora ${ }^{a c}$, Kurz Johanna M.c, de Hoogh Kees ${ }^{\text {de }}$, \\ Usemann Jakob ${ }^{\mathrm{fg}}$, Singer Florian ${ }^{\mathrm{ch}}$, Latzin Philipp ${ }^{\mathrm{c}^{*}}$, Moeller Alexander ${ }^{\mathrm{f}^{*}}$ on behalf of the LUIS study group \\ a Institute of Social and Preventive Medicine, University of Bern, Switzerland \\ b Graduate School for Cellular and Biomedical Sciences, University of Bern, Switzerland \\ c Division of Paediatric Respiratory Medicine and Allergology, Department of Paediatrics, Inselspital, Bern University Hospital, University of Bern, Switzerland \\ d Swiss Tropical and Public Health Institute, Basel, Switzerland \\ e University of Basel, Basel, Switzerland \\ f Division of Respiratory Medicine, University Children's Hospital Zurich and Children's Research Centre, University of Zurich, Switzerland \\ $g$ University Children's Hospital Basel (UKBB), Basel, Switzerland \\ h PEDNET, paediatric clinical trial unit, Children's University Hospital of Bern, University of Bern, Switzerland
}

These authors contributed equally to the work Correspondence: Prof. Alexander Moeller, $M D$, University Children's Hospital Zurich Eleonorenstiftung, Steinwiesstrasse 75, CH-8032 Zurich, alexan-

der.moeller[at]kispi.uzh.ch Author contributions Alexander Moeller, Claudia E. Kuehni and Philipp Latzin conceptualised and designed the study. Rebeca Mozun analysed the data and drafted the manuscript Eva S.L. Pedersen supported the statistical analysis. All authors gave input for interpretation of the data. All authors critically revised and approved the manuscript.
Summary

Respiratory disease is common in children and strongly associated with lifestyle and environmental exposures. Thus, it is important to study the epidemiology locally. The LuftiBus in the School (LUIS) study was set up to assess the respiratory health of schoolchildren in the canton of Zurich, Switzerland.

LUIS is a cross-sectional population-based study that was carried out 2013 to 2016 . Children aged 6-17 years living in the canton of Zurich were eligible to participate. All schools in the canton were approached and the school head decided whether the school would participate and with which classes. Consenting parents answered a standardised questionnaire at home and assenting children completed a shorter questionnaire by interview at school. Trained technicians measured children's lung function, including spirometry, double tracer gas single-breath washout (DTG-SBW) and fractional exhaled nitric oxide (FeNO). Address histories of participants were geocoded to be linked with area-based socioeconomic measures and environmental exposures such as spatiotemporal air pollution estimates for specific time periods and locations. A subgroup was seen again 12 months later using the same procedures to collect longitudinal data.

The study included 3870 children at baseline and 655 at the 1-year follow-up. Median age was 12.7 years; 281 $(8 \%)$ had wheezed in the past year. At baseline we collected 3457 (89\%) parental and $3546(92 \%)$ child questionnaires, and 3393 (88\%) FeNO, 3446 (89\%) spirometry, and 1795 (46\%) DTG-SBW measurements.

LUIS is a rich resource of health-related data, with information on lung function, environmental exposures and respiratory health on Swiss schoolchildren.

\section{Introduction}

Respiratory disease is common and can affect quality of life and school performance in children [1]. Symptoms and diseases result from complex interactions between genetic factors and modifiable behavioural and environmental influences, such as physical activity, passive and active smoking, and air pollution [2]. The prevalence of respiratory symptoms such as wheeze and cough varies widely between countries, so local studies are important [3, 4]. Geographic differences in the prevalence of respiratory diseases may result from differences in lifestyle, health care, socioeconomic factors and environmental exposures, which have been the focus of many studies [2, 3, 5-7].

Previous research on the respiratory health of Swiss children focused on self-reported lower respiratory symptoms and a farming environment [8-14]. None of the recent population-based studies included a detailed assessment of lung function and airway inflammation. Different examinations measure diverse aspects of lung physiology, such as airway inflammation, lung volumes, flows representing function of larger airways, and ventilation inhomogeneity representing the ventilation in peripheral airways. The same symptom might be caused by different underlying mechanisms, and similar underlying mechanisms may cause diverse symptoms in children. Thus, joint evaluation of results from different examinations and of reported symptoms would improve understanding of this complexity. This article explains the methodology of LuftiBus in the School (LUIS) and presents first results.

\section{Study objectives}

LUIS is a multipurpose school-based study on respiratory health in children. Its objectives are: (1) to describe the frequency of common upper and lower respiratory symptoms such as chronic cough, rhinitis, habitual snoring and wheeze reported by schoolchildren and their parents; (2) 
to assess risk factors for respiratory symptoms, with a special interest in lifestyle and environmental exposures such as smoking and air pollution; (3) to study lung function phenotypes, determinants of lung function and associations with lifestyle and environmental exposures; (4) to assess the distribution of lung function (spirometry and double tracer gas single breath washout, [DTG-SBW]) and airway inflammation (fractional exhaled nitric oxide [FeNO]) measurements in healthy schoolchildren and to provide normative data; (5) to gain methodological insights into questionnaire design and performance of novel lung function tests such as DTG-SBW in school-based settings to help guide future research.

\section{Materials and methods}

\section{Study design and setting}

Throughout the manuscript we use the past tense for procedures or analyses that were done in the past and the present or future tense for those that are underway or planned. LUIS is a cross-sectional study that was conducted from November 2013 to December 2016 among schoolchildren aged 6 to 17 years living in the canton of Zurich (ClinicalTrials.gov: NCT03659838). A subsample of children was seen again 1 year later for collection of longitudinal data. The canton of Zurich is located in the north-eastern part of Switzerland and is the most populated canton in the country with over 1.5 million inhabitants, $18 \%$ of the Swiss population [15].

\section{Study procedures}

LUIS was embedded in a respiratory health promotion activity offered by Lunge Zürich [16-18]. Lunge Zürich is a non-profit organisation that promotes respiratory health prevention and research [16]. LUIS used a special bus from Lunge Zürich, the LuftiBus, to visit schools within the canton of Zurich, further details on the LuftiBus are described in the appendix [16]. All school heads in the canton of Zurich were invited to participate (fig. 1). They decided whether to take part in the project and with which class- es, independently of the health status on the students. Participating schools contributed CHF 500 for a 2-day visit and CHF 800 for a visit lasting 1 week, from their reserved budget for health prevention activities in schools. Main reasons for non-participation of schools were lack of time and commitment to other health prevention activities. The study coordinator provided the participating schools with closed envelopes containing study information for parents and for children, and an informed consent form and a questionnaire for parents. Teachers gave these envelopes to the students 2 weeks before the visit. Parents were asked to complete the questionnaire. Two study field workers, who were trained lung function technicians, visited each school with the study bus, the LuftiBus [16]. They collected the parental questionnaires and consent forms from the teachers and asked all students for oral and, where appropriate, written consent. The study bus contained computers and equipment for lung function testing. One field worker measured the children's height and weight and performed the lung function tests, and the other interviewed the children using a short electronic questionnaire.

Where the heads of the participating schools agreed, the school was visited again 1 year later (2015-2016), with the same procedures and the same tests as in the baseline visit.

\section{Study participants}

Eligible were children aged 6 to 17 years, living in the canton of Zurich with consent to participate. Participants were recruited from whole school classes selected for participation by the heads of participating schools. There were no predefined exclusion criteria. However, basic German language knowledge from the children and their parents was required to understand the study information and to complete the questionnaires.

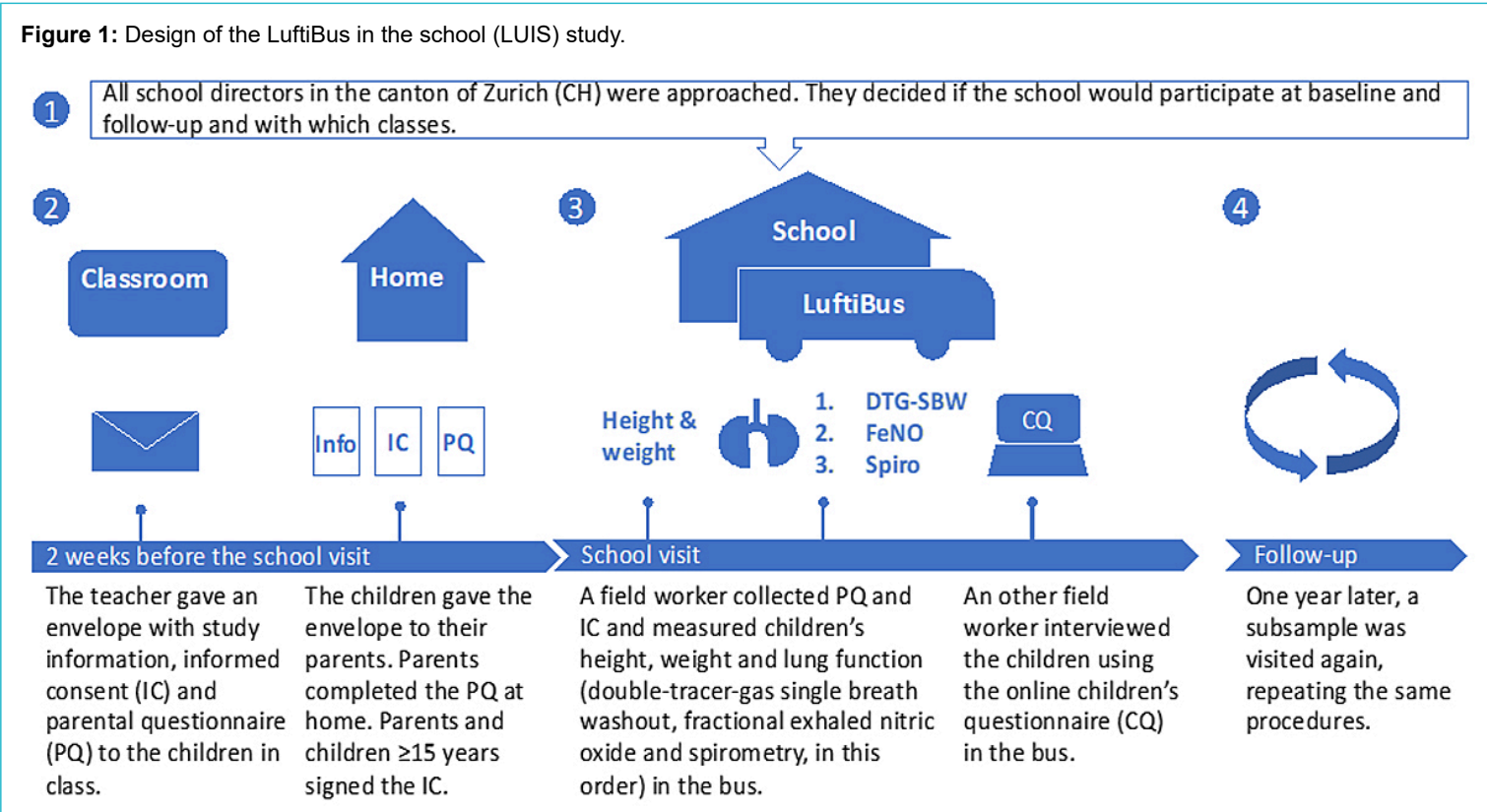




\section{Data collection}

\section{The questionnaires}

The study used two questionnaires: one for parents and one for children. Both included questions on respiratory symptoms and diagnoses including the key questions from the International Study on Asthma and Allergies in Childhood study and additional questions from the Leicester Respiratory Cohort questionnaires [3, 7]. The questionnaire to parents included questions about frequency, duration, severity and triggers of upper and lower respiratory symptoms, doctors' diagnosis of asthma, medication, environmental factors, household characteristics, family history of asthma, and current and past addresses (table 1). We geocoded participant's addresses using a reference file from the Swiss Federal Statistical Office (Neuchâtel) [15]. The data from the parental questionnaire were entered into an Epidata database (version 4.2.0.0, EpiData Association, Denmark) at the Institute for Social and Preventive Medicine (ISPM) in Bern.

Children replied to the questionnaire via interview by the field workers in the bus. It included questions about current respiratory health such as rhinitis, cough and wheeze, the presence of cough or a cold on the day of the school visit, inhaled or oral asthma medication on the day of the visit, active smoking and parental smoking. To help the children correctly report asthma medications, the field workers used a poster with pictures and commercial names of all com- monly used inhaled and oral medications in Switzerland (supplementary fig. S1). Children's answers were directly entered by field workers into the web-based Research Electronic Data Capture (REDCap) database [19].

\section{Area-based index of socioeconomic position in Switzer- land (Swiss-SEP)}

The Swiss-SEP was developed by the Swiss National Cohort (SNC) as an area-based measure of socioeconomic status that incorporates information on rent per square meter, education and occupation of household heads, and number of persons per household room [20, 21]. The Swiss-SEP ranges from 0 (lowest) to 100 (highest). We estimated the Swiss-SEP for our participants by matching the geocodes of our participants addresses to the nearest geocode in the Swiss-SEP dataset. If the address of a participant was missing, we assigned the median Swiss-SEP among participants of the same school. In this manuscript we used a dataset from the SNC to assess the distribution of Swiss-SEP among households from the canton of Zurich with at least one child in school-age (6-17 years) and compared it with the distribution of Swiss-SEP of our study participants.

\section{Lung function measurements}

Children's standing height and weight were measured without shoes and recorded in the spirometry database. Lung function tests were performed inside the bus in the

Table 1: Details of data collected in the LuftiBus in the school (LUIS) study.

\begin{tabular}{|c|c|c|}
\hline \multicolumn{2}{|l|}{ Data sources } & \multirow{2}{*}{$\begin{array}{l}\text { Collected data } \\
\text { Upper and lower respiratory symptoms in the past } 12 \text { months: colds, rhinitis, snoring, cough, wheeze, fre- } \\
\text { quency of wheeze/asthma attacks, triggers of cough and wheeze }[3,7]\end{array}$} \\
\hline \multirow[t]{11}{*}{ 1. Questionnaires } & \multirow[t]{6}{*}{ For parents } & \\
\hline & & Asthma diagnosis and hay fever $[3,7]$ \\
\hline & & $\begin{array}{l}\text { Management of wheeze/asthma in the past } 12 \text { months: number of doctor visits; medication use including } \\
\text { short- and long-acting beta-2 agonists, inhaled corticosteroids, leukotriene receptor antagonists, and antihist- } \\
\text { amines }\end{array}$ \\
\hline & & $\begin{array}{l}\text { Household: Current and past address, living on which floor, type of cooking stove, presence of oven or chim- } \\
\text { ney, living on a farm }\end{array}$ \\
\hline & & $\begin{array}{l}\text { Environment and lifestyle: paternal and maternal smoking indoors or outdoors and number of cigarettes } \\
\text { smoked, physical activity of the child, type of commuting to school, sports outside school, pets at home }\end{array}$ \\
\hline & & $\begin{array}{l}\text { Family: country of birth of the child, country of origin of the parents, siblings, parental education, parental his- } \\
\text { tory of asthma and chronic cough }\end{array}$ \\
\hline & \multirow[t]{5}{*}{ For children } & Currently having a cold; currently coughing \\
\hline & & $\begin{array}{l}\text { Upper and lower respiratory symptoms in the past } 12 \text { months: colds, rhinitis, waking up with a dry mouth as a } \\
\text { proxy for mouth breathing, cough, wheeze, triggers of cough and wheeze }[3,7]\end{array}$ \\
\hline & & Asthma diagnosis and hay fever $[3,7]$ \\
\hline & & $\begin{array}{l}\text { Medication during the day of the visit: inhaled short- and long-acting beta-2 agonists, inhaled corticosteroids, } \\
\text { leukotriene receptor antagonists }\end{array}$ \\
\hline & & $\begin{array}{l}\text { Environment and lifestyle: frequency of active smoking of cigarettes, shishas and e-cigarettes; paternal and } \\
\text { maternal smoking }\end{array}$ \\
\hline \multicolumn{2}{|l|}{ 2. Anthropometrics } & $\begin{array}{l}\text { Height and weight measured in the bus without wearing shoes } \\
\text { Body mass index z-scores calculated using World Health Organization reference tables [37] }\end{array}$ \\
\hline \multirow[t]{3}{*}{ 3. Lung function measurements } & Spirometry & $\begin{array}{l}\text { Masterlab, Jaeger, Würzburg, Germany. Mouthpiece, filter, nasal clamp } \\
\text { Main outcomes: forced expiratory flows and volumes [28] }\end{array}$ \\
\hline & FeNO & $\begin{array}{l}\text { Fast response chemiluminescence analyzer CLD 88, Eco Medics AG, Duernten, Switzerland. Mouthpiece, } \\
\text { filter, no nasal clamp } \\
\text { Main outcome: mean FeNO (ppb) of at least two reproducible exhalations in the same child }[27,43]\end{array}$ \\
\hline & $\begin{array}{l}\text { DTG-SBW } \\
\left(\mathrm{He}, \mathrm{SF}_{6}\right)\end{array}$ & $\begin{array}{l}\text { Exhalyzer D, Eco Medics AG, Duernten, Switzerland. Mouthpiece, filter, nasal clamp [23] } \\
\text { Main outcome: phase III slope }\end{array}$ \\
\hline \multicolumn{2}{|l|}{ 4. Air pollution } & $\begin{array}{l}\text { We will use data from air pollution models developed by de Hoogh et al. [30, 31] to estimate participants' av- } \\
\text { erage exposure to } \mathrm{NO}_{2} \text { and } \mathrm{PM}_{2.5} \text { for specific time windows and locations, based on participants' exact ad- } \\
\text { dress history. }\end{array}$ \\
\hline \multicolumn{2}{|l|}{ 5. Swiss-SEP } & $\begin{array}{l}\text { An area-based measure of socioeconomic status based on data about rent per square meter, education and } \\
\text { occupation of households' heads, and household crowding, which ranges from } 0 \text { (lowest) to } 100 \text { (highest), } \\
\text { developed as part of the Swiss National Cohort study }[20,21]\end{array}$ \\
\hline
\end{tabular}

FeNO = Fractional exhaled nitric oxide; ppb = parts per billion; DTG-SBW = double tracer gas single breath washout; $\mathrm{He}=$ helium; $\mathrm{SF}_{6}=$ sulphur hexafluoride; $\mathrm{NO}_{2}=$ nitrogen dioxide; $\mathrm{PM}_{2.5}$ : particulate matter of aerodynamic diameter of $2.5 \mu \mathrm{m}$ or less; Swiss-SEP = socioeconomic position in Switzerland 
following order: (1) double tracer gas single-breath washout (DTG-SBW), (2) fractional exhaled nitric oxide (FeNO), and (3) spirometry.

\section{DTG-SBW}

DTG-SBW was measured using a validated and commercially available setup (Exhalyzer $D^{\circledR}$, Eco Medics AG, Duernten, Switzerland) [22]. The patient interface consisted of a bacterial filter and a snorkel mouthpiece to prevent air leaks near the mouth. According to current paediatric equipment recommendations, a dead space reducer and a disposable hygienic insert provided by the manufacturer were used [23]. The DTG mixture contained 26.3\% helium $(\mathrm{He}), 5 \%$ sulphur hexafluoride $\left(\mathrm{SF}_{6}\right), 21 \%$ oxygen $\left(\mathrm{O}_{2}\right)$, and balance dinitrogen $\left(\mathrm{N}_{2}\right)$ from pressurised cylinders (Carbagas, Bern, Switzerland). Children watched a video for distraction while breathing through an open bypass system. Directly before tracer gas wash-in, the apparatus dead space and the bias flow was flushed with double-tracer gas or $100 \% \mathrm{O}_{2}$ during expiration to prevent re-inspiration of expired or ambient gas [24]. DTG-SBW was performed in accordance with the European Respiratory Society (ERS) consensus on inert gas washout testing [23]: after establishing natural tidal breathing for at least 5 breaths monitored by online flow-volume loops and tidal volumes varying less than $10 \%$, the system was flushed with the DTG mixture. Within only one breath, the children inhaled the double-tracer gas and exhaled it back. SBW tests were done in triplicate. Each test was followed by at least 10 breaths of room air, until the online monitoring of the gas signals returned to baseline [23]. Primary outcome of the DTG-SBW was the mean slope from the tidal (alveolar) phase III from three technically acceptable DTG-SBW curves, normalised for tidal volume (SnIII) [25]. The magnitude of phase III slopes from $\mathrm{He}$ and $\mathrm{SF}_{6}$ relates to acinar branching asymmetry and small airways obstruction [26]. DTG-SBW is a fast and easy to perform test with low variability and high repeatability [22].

\section{FeNO}

FeNO was measured with a single breath on-line method according to recommendations [27]. We used a fast response chemiluminescence analyser CLD 88, Eco Medics AG, Duernten, Switzerland. The field workers calibrated the FeNO device every morning and the gas was calibrated once per month. Children breathed air free of nitric oxide via the Denox system (EcoMedics, Dürnten). This setup also included a bacterial filter and disposable hygienic mouthpiece. After 10 breaths, children exhaled against an adjusted expiratory resistance with a constant target flow of $50 \mathrm{ml} / \mathrm{sec}$ for at least 4 seconds for children younger than 12 years and 6 seconds for children aged 12 years or older. We aimed for at least two reproducible exhalations with the nitric oxide plateau values within $10 \%$ of each other. Results were stored digitally, including information on FeNO (parts per billion, ppb), expiratory time (seconds), duration of the plateau (seconds), and average flow in the plateau $(\mathrm{ml} / \mathrm{s})$. The primary outcome was FeNO.

\section{Spirometry}

Spirometry was performed using Masterlab, Jaeger, Würzburg, Germany according to American Thoracic Society (ATS) / ERS recommendations [28]. The children performed three to five forced expiratory manoeuvres. Spirometry parameters were recorded and stored digitally using the Sentry Suite software, Carefusion, Hoechberg, Germany. Spirometry parameters included forced vital capacity (FVC), forced expiratory volume in the first second $\left(\mathrm{FEV}_{1}\right)$, peak expiratory flow $(\mathrm{PEF}), \mathrm{FEV}_{1} / \mathrm{FVC}$ ratio, maximum expiratory flow at $75 \%, 50 \%$ and $25 \% \mathrm{FVC}$ $\left(\mathrm{FEF}_{75}, \mathrm{FEF}_{50}, \mathrm{FEF}_{25}\right)$ and between the $25 \%$ and $75 \%$ of FVC $\left(\mathrm{FEF}_{25-75}\right)$. The spirometry flow-volume curve of the best effort was printed on paper. Primary outcomes were forced expiratory flows and volumes. Absolute values of spirometry parameters were expressed as z-scores according to Global Lung Initiative reference values [29].

\section{Air pollution assessment}

Spatiotemporal data on nitrogen dioxide $\left(\mathrm{NO}_{2}\right)$ and particulate matter with an aerodynamic diameter of $2.5 \mu \mathrm{m}$ or less $\left(\mathrm{PM}_{2.5}\right)$ will be obtained from models developed by de Hoogh et al. [30, 31]. Daily average $\mathrm{NO}_{2}$ concentrations were modelled across Switzerland using a multistage framework with mixed-effect and random forest models at a fine spatial resolution of $100 \times 100 \mathrm{~m}$ [30] combining the Ozone Monitoring Instrument (OMI) $\mathrm{NO}_{2}$ product with Copernicus Atmosphere Monitoring Service (CAMS), land use and meteorological variables. Daily $\mathrm{PM}_{2.5}$ concentrations across Switzerland were estimated first by a combination of a mixed effect model and a generalised additive mixed model at a $1 \times 1 \mathrm{~km}$ resolution using Multiangle Implementation of Atmospheric Correction (MAIAC), spectral aerosol optical depth (AOD) data, and second by support vector machine algorithms used to predict precise exposure estimates at a $100 \times 100 \mathrm{~m}$ resolution with spatiotemporal predictor data [31]. These air pollution models allow estimation of participants' average exposure to $\mathrm{NO}_{2}$ and $\mathrm{PM}_{2.5}$ for specific time windows and locations. We will link the geocoded residential and school addresses of study participants to $\mathrm{NO}_{2}$ and $\mathrm{PM}_{2.5}$ data by GIS (geographic information system) overlay.

\section{Ethics and data safety}

The ethics committee of the canton of Zurich approved the study (KEK-ZH-Nr: 2014-0491). Parents signed the informed consent form and completed a detailed questionnaire. Children assented orally and those aged 15 years or older also signed. Participant identifiable information was stored in a separate database and only pseudoanonymised datasets are used for analysis. Paper-based data were securely locked at ISPM and only accessible to the study team. Raw data of DTG-SBW, FeNO and spirometry measurements were stored in a safe study server during recruitment and were thereafter encrypted and securely stored in the ISPM protected server. Access to the server and the study databases is restricted to members of the study team. Study datasets are securely stored and routinely backed up in protected servers of ISPM Bern. Study collaborators and other researchers can obtain datasets for analysis if a detailed concept sheet is presented for the planned analyses and approved by the principal investigators (AM, PL and CK).

\section{Sample size considerations}

We aimed to recruit over 3000 children to address the main objectives of the LUIS study. In this section we describe 
examples of sample size estimations for our main aims [32]. LUIS aimed to describe the frequency of respiratory symptoms in schoolchildren. To estimate the prevalence of current wheeze we need a sample size of 2501 participants, if we assume a level of acceptable error of $1 \%$ [3], and we expect a proportion of wheeze in the population of around $7 \%$ [14], at the 5\% type I error rate (i.e., $\alpha=0.05$ ). Another study aim was to assess risk factors for respiratory symptoms. If we expect the proportion of wheeze to be $7 \%$ higher among students who smoke compared with never smokers [33], and a proportion of smokers of $15 \%$ [34], to be $80 \%$ certain of detecting a prevalence difference at the $5 \%$ Type I error rate, we need a sample with 160 smokers and 890 never smokers. LUIS also aimed to examine associations between lung function measurements and environmental exposures. If we want to compare the difference in $\mathrm{FEV}_{1}(\mathrm{ml})$ between a group of participants with high exposure to air pollution (e.g., $\mathrm{PM}_{2.5}$ ) with a group with lower exposure levels, using a two-sided $5 \%$ significance test (i.e., $\alpha=0.05$ ), to be $80 \%$ sure of detecting a difference of $-50 \mathrm{ml}$ between the high and the low exposure groups, with an estimated standard deviation of $\mathrm{FEV}_{1}$ of $326 \mathrm{ml}$ [35], we need at least 668 participants per group. LUIS data will be used to assess the fit of global lung function initiative (GLI) reference equations, for which we need at least 150 healthy boys and girls of white ethnicity $[29,36]$. If we want to assess the fit of GLI for several age groups, at least 300 children per age group are needed. At follow-up, we aimed to re-visit a sub-sample of 1000 children for longitudinal analyses.

\section{Data preparation and analysis}

We calculated body mass index (BMI) z-scores according to World Health Organization references and categorised BMI z-scores $\geq 2$ as obesity, $\geq 1$ to $<2$ as overweight and $\leq-2$ as underweight [37]. In this manuscript, we compared participants' characteristics between age groups using pvalues for a trend. We used the software STATA (Version 16.1, StataCorp., College Station, TX) for statistical analysis. In our planned analyses, we will select confounders a priori based on Directed Acyclic Graphs (DAGs). Results from DTG-SBW, FeNO or spirometry tests that did not meet the quality standards described in the appendix will not be included in analyses. Details on data quality assessments can be found in the appendix. We will adhere to STROBE reporting guidelines in manuscripts using LUIS datasets [38].

\section{Results}

\section{Participating schools}

All 490 schools in the canton of Zurich were invited to participate (supplementary table $\mathrm{S} 1$ in the appendix). At baseline, 37 schools took part and 3870 participants consented. One year later, 19 schools were visited a second time and 655 children were followed up. The canton of Zurich (fig. 2) had mostly schools in small (47\%) and large urban areas $(41 \%)$ and fewer in rural areas (12\%) (fig. 3, online Table S1) $[39,40]$. At baseline, LUIS visited 18 schools in small $(49 \%)$ and 15 in large (40\%) urban areas and 4 in rural areas (11\%). At follow up, 13 schools in small $(68 \%)$ and 4 in large (21\%) urban areas and 2 in rural areas $(11 \%)$ were visited. Median Swiss-SEP was 66.2 (interquartile range
[IQR] 58.2-73.0) for households with at least one schoolaged child in the canton of Zurich, 69.2 (IQR 61.2-76.3) for LUIS participants at baseline and 69.4 (IQR 64.7-74.8) at follow-up (fig. 4, supplementary fig. S2).

\section{Completeness of datasets}

At baseline, 3457 participants $(89 \%)$ provided parental questionnaires, 3546 (92\%) answered the children's questionnaire, 3446 (89\%) did spirometry, 3393 (88\%) FeNO and 1795 (46\%) DTG-SBW tests (supplementary table S2

Figure 2: Areas from the canton of Zurich that were visited by the LuftiBus in the School (LUIS) study. The area of the circle is proportional to the number of participants per location. The colour of the circle indicates the degree of urbanisation of the region (from darker to lighter grey: large urban, small urban, rural areas) according to the Swiss Federal Office of Statistics classification. Definition of urbanisation degree: cities or large urban area: at least $50 \%$ lives in high-density clusters. Towns and suburbs or small urban area: less than $50 \%$ of the population living in rural grid cells and less than $50 \%$ living in a high-density cluster. Rural area: more than $50 \%$ of the population living in rural grid cells.

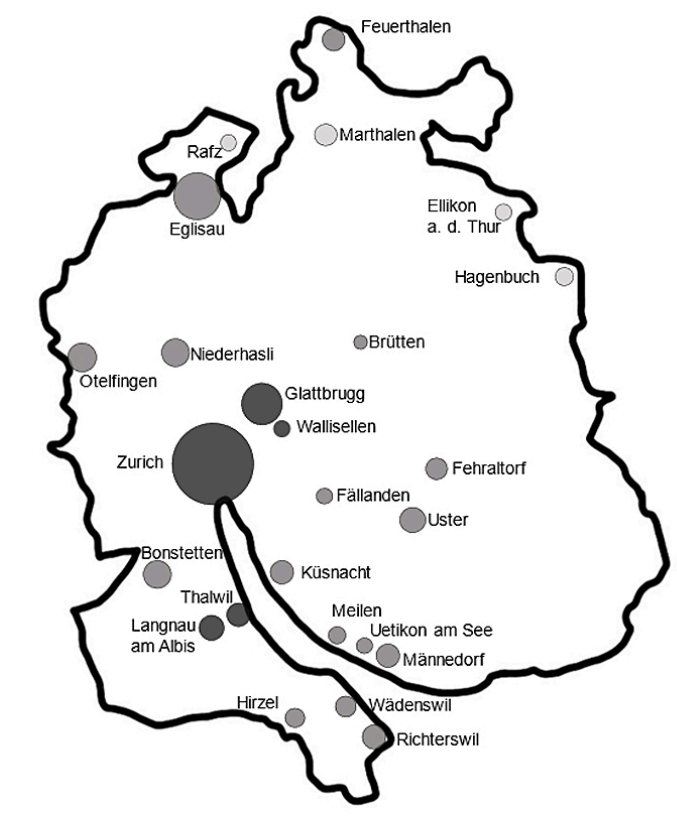

Figure 3: Proportion of schools by degree of urbanisation in the canton of Zurich and in the LuftiBus in the School (LUIS) study at baseline and follow-up. Definition of urbanisation degree: cities or large urban area: at least $50 \%$ lives in high-density clusters. Towns and suburbs or small urban area: less than $50 \%$ of the population living in rural grid cells and less than $50 \%$ living in a high-density cluster. Rural area: more than $50 \%$ of the population living in rural grid cells.

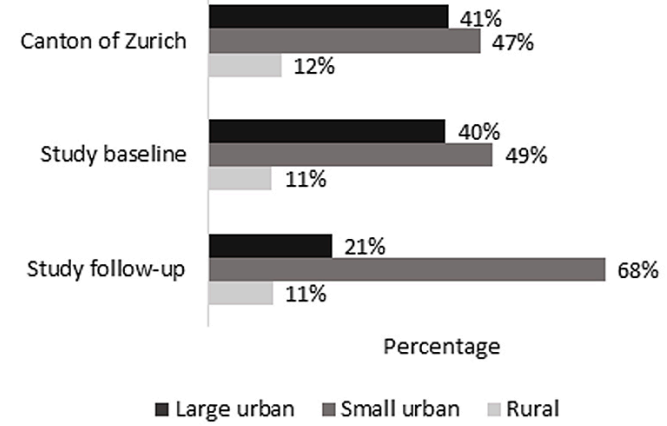


in the appendix). At the 1-year follow-up, data from parental questionnaires was available for 629 children (96\%), data from children's questionnaires for $640(98 \%)$, results from spirometry for 614 (94\%), results from FeNO testing for $588(90 \%)$ and results from DTG-SBW for 496 children (76\%).

Figure 4: Box plots showing the distribution of Swiss socioeconomic position index (Swiss-SEP) for families with at least one child aged 6-17 years and living in the canton of Zurich and in the LuftiBus in the School (LUIS) study at baseline and follow-up. The median is represented by a horizontal line inside the box, 25 and 75 percentiles by the upper and lower box horizontal lines of the box, minimum and maximum values are shown as whiskers, and points outside the whiskers are outliers.
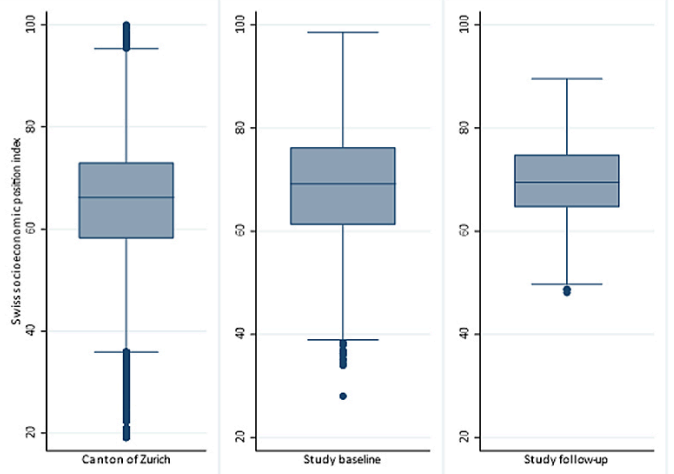

Characteristics of study participants and first results

LUIS included 987 children aged 6-9 years (2\%), 1723 aged $10-13$ years (45\%) and 1160 aged $14-17$ years $(30 \%)$ at baseline (table 2). Current wheeze was reported by parents of $281(8 \%)$ children. Exercise-induced wheeze was more common among older children, and night cough among younger children. Use of inhaled short-acting beta-2 agonists (SABA) and inhaled corticosteroid (ICS) in the past year was reported by parents of $257(8 \%)$ and 179 (5\%) children, respectively. Parents of 1108 (32\%) reported that their child had a high physical activity level. This was more common for younger children. Mothers of 574 $(17 \%)$ and fathers of $758(22 \%)$ children reported smoking. A total of 580 children (15\%) were overweight and 194 (5\%) obese, with obesity being more common in older children. Most children were born in Switzerland $(\mathrm{n}=$ $3042 ; 88 \%$ ), but only over half of children's mothers ( $\mathrm{n}=$ $1934 ; 56 \%)$ and fathers $(\mathrm{n}=2045 ; 59 \%)$.

The volume of air that was exhaled in the first second $\left(\mathrm{FEV}_{1}\right)$ was higher in boys (median $2556 \mathrm{ml}$, IQR 1963-3358) than in girls (2485 ml, IQR 1910-2953) and increased with age, particularly during the pubertal growth spurt (fig. 5).

FeNO had a right skewed distribution. Median (IQR) values of FeNO were $12.9 \mathrm{ppb}(7.3-24)$ in boys and 12.0 ppb (7.0-19.2) in girls (fig. 6). FeNO levels were lower in younger than in older in children with reported hay fever (age 6-9 years: median 11.9 ppb, IQR 6.5-24.3; age 10-13 years: $20.9 \mathrm{ppb}, 10.6-43.9$; age 14-17 years: $20.1 \mathrm{ppb}$, 11.6-39.3) and also in children without hay fever (age 6-9

Table 2: LuftiBus in the School (LUIS) study: characteristics of the study participants.

\begin{tabular}{|c|c|c|c|c|c|c|}
\hline & & \multirow[t]{2}{*}{ Total } & \multicolumn{3}{|c|}{ Age groups (years) } & \multirow[t]{3}{*}{ P trenc } \\
\hline & & & 6 to 9 & 10 to 13 & 14 to 17 & \\
\hline & & $n=3870$ & $\mathrm{n}=987$ & $\mathrm{n}=1723$ & $n=1160$ & \\
\hline \multicolumn{2}{|l|}{ Male sex } & $1937(50 \%)$ & $509(52 \%)$ & $842(49 \%)$ & $586(51 \%)$ & - \\
\hline \multicolumn{2}{|l|}{ Age in years, mean (SD) } & $12.1(2.7)$ & $8.2(1.0)$ & $12.4(1.2)$ & $15.0(0.7)$ & - \\
\hline \multicolumn{2}{|l|}{ Height for age z-scores, mean (SD) } & $0.55(1.0)$ & $0.76(1.0)$ & $0.51(1.1)$ & $0.45(1.0)$ & $<0.001$ \\
\hline \multicolumn{2}{|c|}{ Body mass index z-scores, mean (SD) } & $0.06(1.2)$ & $-0.06(1.1)$ & $0.04(1.2)$ & $0.19(1.1)$ & $<0.001$ \\
\hline \multirow[t]{4}{*}{ Body mass index } & Underweight (z-score $\leq-2)$ & $139(4 \%)$ & $34(4 \%)$ & $76(4 \%)$ & $29(3 \%)$ & \multirow[t]{4}{*}{0.002} \\
\hline & $\begin{array}{l}\text { Normal weight (z-score }>-2 \text {, } \\
<1)\end{array}$ & $2850(76 \%)$ & $752(80 \%)$ & $1251(74 \%)$ & $847(75 \%)$ & \\
\hline & Overweight (z-score $\geq 1,<2$ ) & $580(15 \%)$ & $126(13 \%)$ & $276(16 \%)$ & $178(16 \%)$ & \\
\hline & Obese (z-score $\geq 2$ ) & $194(5 \%)$ & $33(3 \%)$ & $93(5 \%)$ & $68(6 \%)$ & \\
\hline \multirow[t]{3}{*}{ Level of physical activity } & Low & $332(10 \%)$ & $26(3 \%)$ & $140(9 \%)$ & $166(18 \%)$ & \multirow[t]{3}{*}{$<0.001$} \\
\hline & Moderate & $1976(58 \%)$ & $484(51 \%)$ & $928(60 \%)$ & $564(61 \%)$ & \\
\hline & High & $1108(32 \%)$ & $443(46 \%)$ & $475(31 \%)$ & $190(21 \%)$ & \\
\hline \multicolumn{2}{|l|}{ Practice of sports outside school } & $2612(76 \%)$ & $767(81 \%)$ & $1216(79 \%)$ & $629(68 \%)$ & $<0.001$ \\
\hline \multirow[t]{5}{*}{ Symptoms in the past 12 months } & Wheeze & $281(8 \%)$ & $75(8 \%)$ & $137(9 \%)$ & $69(8 \%)$ & 0.864 \\
\hline & Exercise-induced wheeze & $274(8 \%)$ & $43(5 \%)$ & $134(9 \%)$ & $97(11 \%)$ & $<0.001$ \\
\hline & Night cough apart from colds & $394(12 \%)$ & $142(15 \%)$ & $154(10 \%)$ & $98(11 \%)$ & 0.003 \\
\hline & Rhinitis apart from colds & $1049(31 \%)$ & $217(23 \%)$ & $501(33 \%)$ & $331(36 \%)$ & $<0.001$ \\
\hline & $\begin{array}{l}\text { Habitual snoring (almost every } \\
\text { night) }\end{array}$ & $163(5 \%)$ & $55(6 \%)$ & $60(4 \%)$ & $48(5 \%)$ & 0.584 \\
\hline \multirow{2}{*}{$\begin{array}{l}\text { Use of inhaled medication in the } \\
\text { past } 12 \text { months }\end{array}$} & Short acting beta- 2 agonists & $257(8 \%)$ & $63(7 \%)$ & $123(8 \%)$ & $71(8 \%)$ & 0.344 \\
\hline & Inhaled corticosteroids & $179(5 \%)$ & $36(4 \%)$ & $90(6 \%)$ & $53(6 \%)$ & 0.050 \\
\hline \multicolumn{2}{|l|}{ Hay fever } & $767(23 \%)$ & $134(14 \%)$ & $373(25 \%)$ & $260(28 \%)$ & $<0.001$ \\
\hline \multicolumn{2}{|l|}{ Maternal smoking } & $574(17 \%)$ & $121(13 \%)$ & $266(17 \%)$ & $187(20 \%)$ & $<0.001$ \\
\hline \multicolumn{2}{|l|}{ Paternal smoking } & $758(22 \%)$ & $171(18 \%)$ & $335(22 \%)$ & $252(27 \%)$ & $<0.001$ \\
\hline \multicolumn{2}{|l|}{ Pets in the household } & $1469(43 \%)$ & $313(33 \%)$ & $720(47 \%)$ & $436(47 \%)$ & $<0.001$ \\
\hline \multicolumn{2}{|l|}{ Living on a farm } & $85(2 \%)$ & $12(1 \%)$ & $46(3 \%)$ & $27(3 \%)$ & 0.021 \\
\hline
\end{tabular}

Information obtained from the parental questionnaires at baseline. $\mathrm{P}$ trend: $\mathrm{p}$ value for a trend across ordered categories of age groups. Height for age and body mass index z-scores were based on WHO references. 
years: median $7.9 \mathrm{ppb}$, IQR 5.0-13.6; age 10-13 years: 11.6 ppb, 6.9-18.2; age 14-17 years: 14.3 ppb, 9.2-21.8).

\section{Discussion}

LUIS is a large school-based study performed in 2013-2016 in the canton of Zurich, Switzerland, which comprised a thorough assessment of respiratory symptoms, lung function, lifestyle and environmental exposures. LUIS data will help to increase knowledge on respiratory health in schoolchildren by assessing risk factors, studying phenotypes, contributing to normative lung function and airway inflammation data, and providing recommendations for future research.

\section{Strengths and weaknesses}

The main strength of LUIS is the wealth of health data that were collected, which includes three different lung function tests: spirometry, FeNO measured using high resolution equipment and the novel DTG-SBW. This permits the investigation of different physiological aspects of lung health. A subsample of participants had repeat lung function measurements a year later, which allows assessment of lung growth. We collected detailed questionnaire data on respiratory symptoms, diagnoses and lifestyle from both parents and children, which allows comparisons between their answers. Information was collected on lower respiratory symptoms such as wheeze and chronic cough, and on

Figure 5: Distribution of forced expiratory volume in one second $\left(\mathrm{FEV}_{1}\right)$ by age and sex in children from the LuftiBus in the School (LUIS) study at baseline. $\mathrm{FEV}_{1}$ measured in litres (L)

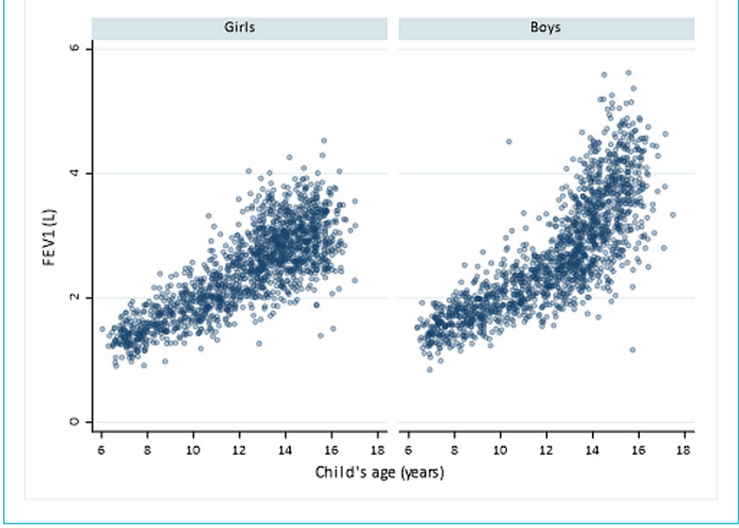

Figure 6: Distribution of fractional exhaled nitric oxide (FeNO) by sex in children from the LuftiBus in the School (LUIS) study at baseline. FeNO measured in parts per billion (ppb).

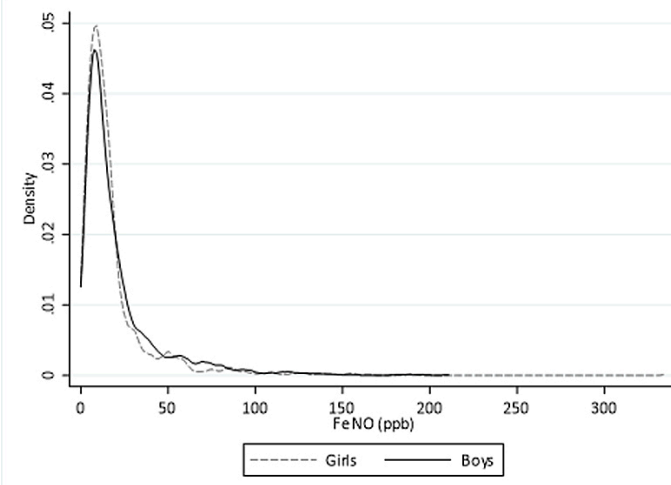

upper respiratory symptoms such as rhinitis, hay fever and snoring. Respiratory symptoms are influenced by seasonality, but the LuftiBus visited the schools throughout different seasons, which makes it possible to take seasonality into account in our analyses. Participants' address histories enable us to use state-of-the-art methods $[30,31]$ to estimate air pollution exposure during specific time windows.

The main weakness is that it was not a perfectly random sample of schoolchildren. Participation was decided by the heads of the schools, and classes were recruited as a whole. We do not have individual data on non-participating students, which limits the possibilities to assess representativeness of the sampled population. However, the distribution of participating schools in rural and urban areas at baseline was similar to the average distribution of schools in the canton of Zurich. At follow-up, schools from small urban areas were slightly overrepresented in our study. The cost associated with the health promotion activity in which the LUIS study was embedded was covered by the public budget for health prevention activities available to school heads. This cost and time availability might have contributed to a school head's decision to participate to the study. The area-based socioeconomic index of participating families was roughly comparable to that of all households with school-aged children from the canton of Zurich. Thus, we think LUIS gives a fair picture of the schoolaged population from the canton of Zurich. We recruited over 3000 participants at baseline, but the sub-sample followed-up was smaller than originally planned because of budget restraints, which limits the possibility of longitudinal analyses. Another limitation is the lack of objective measurements of atopy such as skin prick tests or serum IgE levels. This limits the interpretation of FeNO data. We had, however, proxy measures of atopy, namely reported hay fever and atopic dermatitis.

\section{Outlook}

LUIS will cover knowledge gaps on children's respiratory health. This dataset allows determination of the prevalence of upper and lower respiratory symptoms, description of lifestyle characteristics such physical activity and smoking [41], and a study of associations with lung function. We are able to use information from both parents and children and several lung function tests, including markers of ventilatory function (spirometry), ventilation inhomogeneity (DTGSBW) and Th2 airway inflammation (FeNO), to answer research questions in a comprehensive way [42, 43]. For example, DTG-SBW data allows detection of even subtle changes in peripheral airways, which may not be identified by spirometry alone [42]. The broad set of data collected allows us to describe lung function in healthy children, and to report normal values. The LUIS study makes it also possible to study effects of air pollution on respiratory symptoms and lung function.

In conclusion, LuftiBus in the School (LUIS) provides a unique opportunity to assess the respiratory health of Swiss schoolchildren, and its association with health behaviours and air pollution. Better understanding of factors that influence Swiss schoolchildren's respiratory health may help to establish new recommendations and influence policy makers' decisions. 
The LuftiBus in the school (LUIS) study group

Alexander Moeller and Jakob Usemann (Division of Respiratory Medicine, University Children's Hospital Zurich and Childhood Research Centre, University of Zurich, Switzerland); Philipp Latzin, Florian Singer and Johanna M. Kurz (Division of Paediatric Respiratory Medicine, Children's and Allergology, Department of Paediatrics, Inselspital, Bern University Hospital of Bern, University of Bern, Switzerland); Claudia E. Kuehni, Rebeca Mozun, Cristina Ardura-Garcia, Myrofora Goutaki, Eva S.L. Pedersen and Maria Christina Mallet (Institute of Social and Preventive Medicine, University of Bern, Switzerland); Kees de Hoogh (Swiss Tropical and Public Health Institute, Basel, Switzerland).

The study principal investigators Prof. Alexander Moeller, Prof. Claudia Kuehni and Prof. Philipp Latzin conceptualised and designed the study. Alexander Moeller supervised data collection and was responsible for the overall conduct of the study. Philipp Latzin was responsible for the lung function measurements. Claudia Kuehni was responsible for the questionnaire design and data analysis. Rebeca Mozun was responsible for data management and coordination. Florian Singer and Johanna Kurz are responsible for management and analysis of DTGSBW data. Myrofora Goutaki, Eva S.L. Pedersen, Maria Christina Mallet and Cristina Ardura-Garcia (Institute of Social and Preventive Medicine, University of Bern, Switzerland) support statistical analysis. Jakob Usemann and Kees de Hoogh are responsible for the air pollution data.

\section{Financial disclosure}

Lunge Zürich, Switzerland, funded the study set-up, development and data collection with a grant to Alexander Moeller. Lunge Zürich, Switzerland, and University Children's Hospital Zurich and Children's Research Center, University of Zurich, Switzerland, funds LUIS data management, data analysis and publications. Analysis has been supported by a grant of the Swiss National Science Foundation (320030_173044) to Claudia Kuehni and an Ambizione grant of the Swiss National Science Foundation to Myrofora Goutaki (P200P3_185923). Further analyses are funded by a grant of Lungenliga Bern, Switzerland, to Florian Singer, a grant of Lungenliga Schweiz to Jakob Usemann and a grant of Stiftung Batzebär to Johanna Kurz.

\section{Conflicts of interest}

Dr Moeller reports grants from Lunge Zuerich, personal fees from Vertex Inc., during the conduct of the study. Dr Singer reports personal fees from Novartis, personal fees from Vertex, outside the submitted work. Dr Usemann reports personal fees from Vertex, during the conduct of the study. Dr Latzin reports personal fees from Vertex, personal fees from Novartis, personal fees from Roche, personal fees from Polyphor, personal fees from Vifor, personal fees from Gilead, personal fees from Schwabe, personal fees from Zambon, personal fees from Santhera, grants from Vertex, outside the submitted work.

\section{Acknowledgements}

We thank the school teams and the families for participating in the study. We thank the field workers and study personnel for conducting the study. We thank Andras Soti, Marc-Alexander Oestreich, Corin Willers (Paediatric Respiratory Medicine, Children's University Hospital of Bern, University of Bern, Switzerland), Léonie Hüsler, Eugénie Collaud and Carmen C. M. de Jong (Institute of Social and Preventive Medicine, University of Bern, Switzerland) for their help in the assessment of the quality of the spirometry flow-volume curves. We thank Claudia Berlin and the Swiss National Cohort (SNC) (www.swissnationalcohort.ch) for providing data on the Swiss-SEP for the canton of Zurich. We thank the Swiss Federal Statistical Office for providing data on schools and urbanisation degree of municipalities in the canton of Zurich.

\section{References}

1 Ferrante G, La Grutta S. The Burden of Pediatric Asthma. Front Pediatr 2018;6:186. doi: http://dx.doi.org/10.3389/fped.2018.00186. PubMed.

2 Lau S, Nickel R, Niggemann B, Grüber C, Sommerfeld C, Illi S, et al.; MAS Group. The development of childhood asthma: lessons from the German Multicentre Allergy Study (MAS). Paediatr Respir Rev. 2002;3(3):265-72. doi: http://dx.doi.org/10.1016/

S1526-0542(02)00189-6. PubMed.

3 Asher MI, Keil U, Anderson HR, Beasley R, Crane J, Martinez F, et al. International Study of Asthma and Allergies in Childhood (ISAAC): ra- tionale and methods. Eur Respir J. 1995;8(3):483-91. doi: http://dx.doi.org/10.1183/09031936.95.08030483. PubMed.

4 Pearce N, Aït-Khaled N, Beasley R, Mallol J, Keil U, Mitchell E, et al.; ISAAC Phase Three Study Group. Worldwide trends in the prevalence of asthma symptoms: phase III of the International Study of Asthma and Allergies in Childhood (ISAAC). Thorax. 2007;62(9):758-66. doi: http://dx.doi.org/10.1136/thx.2006.070169. PubMed.

5 Selby A, Munro A, Grimshaw KE, Cornelius V, Keil T, Grabenhenrich $\mathrm{L}$, et al. Prevalence estimates and risk factors for early childhood wheeze across Europe: the EuroPrevall birth cohort. Thorax. 2018;73(11):1049-61. doi: http://dx.doi.org/10.1136/thoraxjnl-2016-209429. PubMed.

6 Custovic A, Simpson BM, Murray CS, Lowe L, Woodcock A; NAC Manchester Asthma and Allergy Study Group. The National Asthma Campaign Manchester Asthma and Allergy Study. Pediatr Allergy Immunol. 2002;13(s15):32-7. doi: http://dx.doi.org/10.1034/ j.1399-3038.13.s.15.3.x. PubMed.

7 Kuehni CE, Brooke AM, Strippoli MP, Spycher BD, Davis A, Silverman M. Cohort profile: the Leicester respiratory cohorts. Int J Epidemiol. 2007;36(5):977-85. doi: http://dx.doi.org/10.1093/ije/dym090. PubMed.

8 Sennhauser FH, Kühni CE. Prevalence of respiratory symptoms in Swiss children: is bronchial asthma really more prevalent in boys? Pediatr Pulmonol. 1995;19(3):161-6. doi: http://dx.doi.org/10.1002/ ppul.1950190304. PubMed.

9 Alfvén T, Braun-Fahrländer C, Brunekreef B, von Mutius E, Riedler J, Scheynius A, et al., PARSIFAL study group. Allergic diseases and atopic sensitization in children related to farming and anthroposophic lifestyle--the PARSIFAL study. Allergy. 2006;61(4):414-21. doi http://dx.doi.org/10.1111/j.1398-9995.2005.00939.x. PubMed.

10 Frei R, Roduit C, Bieli C, Loeliger S, Waser M, Scheynius A, et al.; as part of the PARSIFAL study team. Expression of genes related to antiinflammatory pathways are modified among farmers' children. PLoS One. 2014;9(3):e91097. doi: http://dx.doi.org/10.1371/journal.pone.0091097. PubMed.

11 Riedler J, Braun-Fahrländer C, Eder W, Schreuer M, Waser M, Maisch $\mathrm{S}$, et al.; ALEX Study Team. Exposure to farming in early life and development of asthma and allergy: a cross-sectional survey. Lancet. 2001;358(9288):1129-33. doi: http://dx.doi.org/10.1016/ S0140-6736(01)06252-3. PubMed.

12 Illi S, Depner M, Genuneit J, Horak E, Loss G, Strunz-Lehner C, et al.; GABRIELA Study Group. Protection from childhood asthma and allergy in Alpine farm environments-the GABRIEL Advanced Studies. J Allergy Clin Immunol. 2012;129(6):1470-7.e6. doi: http://dx.doi.org/ 10.1016/j.jaci.2012.03.013. PubMed.

13 Braun-Fahrländer C, Gassner M, Grize L, Takken-Sahli K, Neu U, Stricker T, et al.; Swiss Study on Childhood Allergy and Respiratory symptoms; Air Pollution (SCARPOL) team. No further increase in asthma, hay fever and atopic sensitisation in adolescents living in Switzerland. Eur Respir J. 2004;23(3):407-13. doi: http://dx.doi.org/10.1183/ 09031936.04.00074004. PubMed.

14 Grize L, Gassner M, Wüthrich B, Bringolf-Isler B, Takken-Sahli K, Sennhauser FH, et al.; Swiss Surveillance Programme on Childhood Allergy and Respiratory symptoms with respect to Air Pollution (SCARPOL) team. Trends in prevalence of asthma, allergic rhinitis and atopic dermatitis in 5-7-year old Swiss children from 1992 to 2001 . Allergy. 2006;61(5):556-62. doi: http://dx.doi.org/10.1111/ j.1398-9995.2006.01030.x. PubMed.

15 Stocks J, Sonnappa S, Lum S. Lung function testing in children: importance of race and ethnic-specific reference equations. Expert Rev Respir Med. 2014;8(5):527-31. doi: http://dx.doi.org/10.1586/ 17476348.2014.927317. PubMed.

16 Lunge Zürich. [cited 2020 June 02]; Available from: https://www.lungezuerich.ch/de/projekte/luftibus/info-luftibus/?oid=1116\&lang=de

17 Rochat MK, Laubender RP, Kuster D, Braendli O, Moeller A, Mansmann U, et al. Spirometry reference equations for central European populations from school age to old age. PLoS One. 2013;8(1):e52619-52619. doi: http://dx.doi.org/10.1371/journal.pone.0052619. PubMed.

18 West EA, Strassmann A, Wang C, Turk A, de Hoogh K, Röösli M, et al. Increase in Airway Obstruction between 1993 and 2012 in Switzerland. An Observational Study. Ann Am Thorac Soc. 2020;17(4):457-65. doi: http://dx.doi.org/10.1513/AnnalsATS.201907-542OC. PubMed.

19 Harris PA, Taylor R, Minor BL, Elliott V, Fernandez M, O’Neal L, et al.; REDCap Consortium. The REDCap consortium: Building an international community of software platform partners. J Biomed Inform. 2019;95:103208. doi: http://dx.doi.org/10.1016/j.jbi.2019.103208. PubMed. 
20 Bopp M, Spoerri A, Zwahlen M, Gutzwiller F, Paccaud F, BraunFahrländer C, et al. Cohort Profile: the Swiss National Cohort--a longitudinal study of 6.8 million people. Int J Epidemiol. 2009;38(2):379-84. doi: http://dx.doi.org/10.1093/ije/dyn042. PubMed.

21 Panczak R, Galobardes B, Voorpostel M, Spoerri A, Zwahlen M, Egger M; Swiss National Cohort and Swiss Household Panel. A Swiss neighbourhood index of socioeconomic position: development and association with mortality. J Epidemiol Community Health. 2012;66(12):1129-36. doi: http://dx.doi.org/10.1136/jech-2011-200699. PubMed.

22 Singer F, Stern G, Thamrin C, Fuchs O, Riedel T, Gustafsson P, et al. Tidal volume single breath washout of two tracer gases--a practical and promising lung function test. PLoS One. 2011;6(3):e17588. doi: http://dx.doi.org/10.1371/journal.pone.0017588. PubMed.

23 Robinson PD, Latzin P, Verbanck S, Hall GL, Horsley A, Gappa M, et al. Consensus statement for inert gas washout measurement using multiple- and single- breath tests. Eur Respir J. 2013;41(3):507-22. doi: http://dx.doi.org/10.1183/09031936.00069712. PubMed.

24 Singer F, Stern G, Thamrin C, Abbas C, Casaulta C, Frey U, et al. A new double-tracer gas single-breath washout to assess early cystic fibrosis lung disease. Eur Respir J. 2013;41(2):339-45. doi: http://dx.doi.org/ 10.1183/09031936.00044312. PubMed.

25 Aurora P, Kozlowska W, Stocks J. Gas mixing efficiency from birth to adulthood measured by multiple-breath washout. Respir Physiol Neurobiol. 2005;148(1-2):125-39. doi: http://dx.doi.org/10.1016/j.resp.2005.05.027. PubMed.

26 Van Muylem A, Paiva M, Baran D, Yernault JC. Structural change of the acinus during growth assessed by single-breath tracer gas washouts. Pediatr Pulmonol. 1996;22(4):230-5. doi: http://dx.doi.org/ 10.1002/(SICI)1099-0496(199610)22:4\&lt;230::AIDPPUL2\&gt;3.0.CO;2-O. PubMed.

27 Araya-Cloutier C, Vincken J, Van De Schans M, Hageman J, Schaftenaar G, Den Besten H, et al., European Respiratory Society. ATS/ERS recommendations for standardized procedures for the online and offline measurement of exhaled lower respiratory nitric oxide and nasal nitric oxide, 2005. Am J Respir Crit Care Med. 2005;171(8):912-30. doi: http://dx.doi.org/10.1164/rccm.200406-710ST. PubMed.

28 Miller MR, Hankinson J, Brusasco V, Burgos F, Casaburi R, Coates A, et al.; ATS/ERS Task Force. Standardisation of spirometry. Eur Respir J. 2005;26(2):319-38. doi: http://dx.doi.org/10.1183/ 09031936.05.00034805. PubMed.

29 Quanjer PH, Stanojevic S, Cole TJ, Baur X, Hall GL, Culver BH, et al.; ERS Global Lung Function Initiative. Multi-ethnic reference values for spirometry for the 3-95-yr age range: the global lung function 2012 equations. Eur Respir J. 2012;40(6):1324-43. doi: http://dx.doi.org/ 10.1183/09031936.00080312. PubMed.

30 de Hoogh K, Saucy A, Shtein A, Schwartz J, West EA, Strassmann A, et al. Predicting Fine-Scale Daily $\mathrm{NO}_{2}$ for 2005-2016 Incorporating OMI Satellite Data Across Switzerland. Environ Sci Technol. 2019;53(17):10279-87. doi: http://dx.doi.org/10.1021/acs.est.9b03107. PubMed.

31 de Hoogh K, Heritier H, Stafoggia M, Kunzli N, Kloog I. Modelling daily PM2.5 concentrations at high spatio-temporal resolution across
Switzerland. Environ Pollut. 2018;233:1147-54. doi: http://dx.doi.org 10.1016/j.envpol.2017.10.025.

32 Wang X, Ji X. Sample Size Estimation in Clinical Research: From Randomized Controlled Trials to Observational Studies. Chest. 2020;158(1S):S12-20. doi: http://dx.doi.org/10.1016/ j.chest.2020.03.010. PubMed.

33 Mallol J, Castro-Rodriguez JA, Cortez E. Effects of active tobacco smoking on the prevalence of asthma-like symptoms in adolescents. Int J Chron Obstruct Pulmon Dis. 2007;2(1):65-9. doi: http://dx.doi.org/ 10.2147/copd.2007.2.1.65. PubMed.

34 Inchley J, Currie D, Budisavljevic S, Torsheim T, Jåstad A. Cosma Aea Spotlight on adolescent health and well-being. Findings from the 2017/ 2018 Health Behaviour in School-aged Children (HBSC) survey in Europe and Canada. Volume 2. Key data. Copenhagen: WHO Regional Office for Europe. 2020

35 Gauderman WJ, Avol E, Gilliland F, Vora H, Thomas D, Berhane K, et al. The effect of air pollution on lung development from 10 to 18 years of age. N Engl J Med. 2004;351(11):1057-67. doi: http://dx.doi.org/ 10.1056/NEJMoa040610. PubMed.

36 Quanjer PH, Stanojevic S. Do the Global Lung Function Initiative 2012 equations fit my population? Eur Respir J. 2016;48(6):1782-5. doi: http://dx.doi.org/10.1183/13993003.01757-2016. PubMed.

37 de Onis M, Onyango AW, Borghi E, Siyam A, Nishida C, Siekmann J. Development of a WHO growth reference for school-aged children and adolescents. Bull World Health Organ. 2007;85(9):660-7. doi: http://dx.doi.org/10.2471/BLT.07.043497. PubMed.

38 von Elm E, Altman DG, Egger M, Pocock SJ, Gøtzsche PC, Vandenbroucke JP; STROBE Initiative. The Strengthening the Reporting of Observational Studies in Epidemiology (STROBE) statement: guidelines for reporting observational studies. J Clin Epidemiol. 2008;61(4):344-9. doi: http://dx.doi.org/10.1016/j.jclinepi.2007.11.008. PubMed.

39 Bundesamt für Statistik. Räumliche Typologien. [cited 2020 May 05]; Available from: https://www.bfs.admin.ch/bfs/de/home/statistiken/querschnittsthemen/raeumliche-analysen/raeumliche-gliederungen/raeumliche-typologien.html

40 EUROSTAT. Verstädterungsgrad (DEGURBA, Degree of Urbanisation). [cited 2020 May 05]; Available from: http://ec.europa.eu/eurostat/de/ web/degree-of-urbanisation/overview

41 Mozun R, Ardura-Garcia C, de Jong CCM, Goutaki M, Usemann J, Singer F, et al. Cigarette, shisha, and electronic smoking and respiratory symptoms in Swiss children: The LUIS study. Pediatr Pulmonol. 2020;55(10):2806-15. doi: http://dx.doi.org/10.1002/ppul.24985. PubMed.

42 Singer F, Abbas C, Yammine S, Casaulta C, Frey U, Latzin P. Abnormal small airways function in children with mild asthma. Chest. 2014;145(3):492-9. doi: http://dx.doi.org/10.1378/chest.13-0784. PubMed.

43 Singer F, Luchsinger I, Inci D, Knauer N, Latzin P, Wildhaber JH, et al. Exhaled nitric oxide in symptomatic children at preschool age predicts later asthma. Allergy. 2013;68(4):531-8. doi: http://dx.doi.org/10.1111/ all.12127. PubMed. 


\section{Appendix}

\section{Table of contents}

Additional methods

Table S1: Characteristics of schools in the canton of Zurich and visited by the LuftiBus in the school study (LUIS) at baseline and one-year follow-up by degree of urbanization

Table S2: Number of participants in the LuftiBus in the school (LUIS) study with available information on parental questionnaires (PQ), children's questionnaires (CQ), spirometry (Spiro), and fractional exhaled nitric oxide (FeNO) at baseline and one-year follow-up

Figure S1: Poster of asthma medications used in the LuftiBus in the school (LUIS) study to help children answer which medication they had taken the day of the visit (in German)

Figure S2: Histograms showing the distribution of the Swiss socioeconomic position index for families from the canton of Zurich with at least one child aged 6-17 years living in the household and in the LuftiBus in the school (LUIS) study at baseline and one year follow-up

Figure S3: Fit lines of double tracer gas single breath washout (DTG-SBW), differences in molar mass (MM) plotted against expired volume 


\section{Additional methods}

LuftiBus in the school (LUIS) is a study funded by Lunge Zürich, a non-profit organization that promotes respiratory health prevention and research. LUIS used a special bus ("LuftiBus") to visit schools within the canton of Zurich. Inclusion criteria were consent to participate and age 6 to 17 years. There were no predefined exclusion criteria.

\section{LuftiBus}

LuftiBus is a broader project of Lunge Zürich for the prevention and early detection of lung diseases and has been ongoing for 30 years [1,2]. LuftiBus offers lung function tests to adults of the general public living in the metropolitan region of Zurich at a non-profit cost of $10 \mathrm{CHF}$ [3]. Previous research has used data from the LuftiBus lung function campaign to calculate reference equations for lung function $[3,4]$. LuftiBus data was linked with data form the Swiss National Cohort [5] to assess time trends in the prevalence of airway obstruction among adults from the general population [6], occupational risk factors for airway obstruction [7], and spatial risk pattern of respiratory morbidity [8].

\section{Data collection: double tracer gas single breath washout (DTG-SBW)}

The gas mixture had the same molar mass (MM, g.mol-1) as medical-grade air, such that any detectable changes compared with normally expired molar mass can be attributed to relative changes in helium (He) and sulphur hexafluoride $\left(\mathrm{SF}_{6}\right)$ concentrations [9]. MM was measured by a side-stream ultrasonic flowmeter, tidal flows by a main-stream ultrasonic flowmeter. On each test day, signal calibration and verification were performed prior to testing. The main-stream ultrasonic flowmeter was calibrated using a $1 \mathrm{~L}$ precision syringe. The side-stream ultrasonic flowmeter and the oxygen $\left(\mathrm{O}_{2}\right)$ and carbon dioxide $\left(\mathrm{CO}_{2}\right)$ sensors were calibrated using medical-grade calibration gas and pure $\mathrm{O}_{2}$ (Carbagas, Bern, Switzerland).

\section{Air pollution assessments}

Individual air pollution exposure will be estimated for nitrogen dioxide $\left(\mathrm{NO}_{2}\right)$ and for particulate matter with an aerodynamic diameter of $2.5 \mu \mathrm{m}$ or less (PM 2.5) using air pollution models developed by de Hoogh et. al [10, 11]. Daily average $\mathrm{NO}_{2}$ concentrations from 2005 to 2016 were modelled in a multistage framework with mixed-effect and random forest models at a fine spatial resolution (100x100 $\mathrm{m}$ ) [10]. The model incorporates spatial and temporal predictors including satellite-derived data from the Ozone Monitoring Instrument and Copernicus Atmosphere Monitoring Service, and road, land use, topography and meteorological information. Daily $\mathrm{NO}_{2}$ monitoring data were obtained from the Immisionsdatabank Luft (IDB Luft, FOEN, Bern, Switzerland) measured at 67 sites in 2005 and increased to 110 sites in 2016 . The model was able to explain approximately $73 \%$ of the overall spatiotemporal variation in $\mathrm{NO}_{2}$ measurements [10].

Spatiotemporal resolved models were developed to predict daily PM 2.5 exposure [11]. First, daily PM 2.5 concentrations were estimated by a combination of a mixed effect model and a generalized additive mixed model at a $1 \times 1 \mathrm{~km}$ resolution across Switzerland using Multiangle Implementation of Atmospheric Correction (MAIAC) spectral aerosol optical depth (AOD) data. Second, support vector machine algorithms were used to predict precise exposure estimates at a $100 \times 100 \mathrm{~m}$ resolution in using spatiotemporal predictor data. The global $(1 \mathrm{~km})$ and local $(100 \mathrm{~m})$ models explain on average $73 \%$ of the total, $71 \%$ of the spatial and $75 \%$ of the temporal variation globally, and on average $89 \%$ of the total, 
$95 \%$ of the spatial and $88 \%$ of the temporal variation locally in measured PM 2.5 concentrations [11]. From these data we will calculate the mean exposure of each subject to specified air pollution during specific exposure windows.

Other available data on air pollution include ozone in parts per billion, fine particles (number of particles per $\mathrm{cm}^{3}$, average particle diameter in $\mathrm{nm}$, lung-deposited particle surface in $\left.\mathrm{um}^{2} / \mathrm{cm}^{3}\right)$, and temperature and humidity measurements obtained at schools on the day of the study visit using a wireless collection system installed on the roof of the bus in collaboration with the OpenSense team of the ETH (Swiss Federal Institute of Technology in Zurich). The system sent data continuously to a central database at the ETH and sensors were calibrated when the bus passed a reference station.

\section{Data quality}

\section{Parental questionnaires}

The data entry form of the parental questionnaire contained automatic plausibility checks to reduce data entry errors. We did double data entry for a random $10 \%$ of the parental questionnaires using the software Epidata. Variables had one to five entry fields. We found a low field error percentage (1\%) and thus did not double enter the remaining $90 \%$ of questionnaires.

\section{DTG-SBW}

Quality control of DTG-SBW measurements was performed by the field workers on site. A double check of DTG-SBW test results is on-going, to see if the phase III was linear and constituted at least $50 \%$ of expired volume [9, 12]. Quality control criteria for DTG-SBW were defined as: 1) no evidence of air leaks as monitored by volume and MM signals, 2) similar flow-volume-loops in pre-test and test breaths, 3) breath volumes of the five tidal pre-test and the test breaths were within $10 \%, 4$ ) inspiratory peak flow within the by-pass flow.

For signal processing and analyses we used software developed by our group (LungSim, Numerical Modeling, Thalwil, Switzerland) running in (Matlab ${ }^{\circledR}$ R2014a, The Mathworks Inc., Natick, MA, USA) [9]. $\mathrm{MM}, \mathrm{CO}_{2}$ and volume signals were aligned in time accounting for different signal rise times [9]. To extract the double-tracer gas signal from $\mathrm{MM}$ we subtracted the naturally exhaled $\mathrm{CO}_{2}$ fraction from the $\mathrm{MM}$ signal [9]. The corrected $\mathrm{MM}$ and $\mathrm{CO}_{2}$ expirograms were plotted against expired volume (Figure S3). The SDTG was computed automatically by linear regression between 65 to $95 \%$ of expired volume and under visual control. If required, we manually adjusted volume limits to exclude adjacent tidal phases. Quality criteria were presence of both $\mathrm{MM}$ and $\mathrm{CO}_{2}$ phase III over at least $50 \%$ of expired volume.

\section{Fractional exhaled nitric oxide (FeNO)}

Required average flow in the plateau was $40-60 \mathrm{ml} / \mathrm{s}$ and required duration of exhalation was at least 4 seconds for children younger than 12 years and 6 seconds for children aged 12 years or older. Mean FeNO was calculated using at least two reproducible exhalations with the nitric oxide plateau values within $10 \%$ of each other. Field workers checked the quality of the FeNO measurements on site according to ATS/ERS criteria for online FeNO measurement in children [13]. 


\section{Spirometry flow-volume curves}

In a dedicated workshop, a paediatric pulmonologist and lung function expert (FS) explained the fundamental concepts of paediatric spirometry quality control to all participants. Five pairs of team members assessed and scored by consensus the quality of spirometry curves into "good", "moderate" or "bad" quality" depending on the presence of hesitation at start of expiration, submaximal effort, forced flow deviations (e.g. cough or glottis closure) within or after the first second, and premature ending of the exhalation within or after the first second. Three paediatric respiratory physicians (FS, CK, $\mathrm{JU}$ ) assessed all spirometry curves marked as "moderate" or "bad" quality during the first screening and set their own score. If the paediatric respiratory physicians had doubts on the scoring of a spirometry curve, they discussed the curve among them and reached an agreement.

\section{References}

1. Lunge Zürich. [cited 202002 June]; Available from: https://www.lunge-zuerich.ch/de/projekte/luftibus/infoluftibus/?oid=1116\&lang=de

2. Egger S, Wieland R, Ludin M, Brändli O, Vetter W, Suter PM. [Overweight and obesity in the Zurich canton. A LuftiBus study]. Praxis 2001: 90(13): 531-538.

3. Kuster SP, Kuster D, Schindler C, Rochat MK, Braun J, Held L, Brändli O. Reference equations for lung function screening of healthy never-smoking adults aged 18-80 years. Eur Respir J 2008: 31(4): 860-868.

4. Rochat MK, Laubender RP, Kuster D, Braendli O, Moeller A, Mansmann U, von Mutius E, Wildhaber J. Spirometry reference equations for central European populations from school age to old age. PloS one 2013: 8(1): e52619-e52619.

5. Bopp M, Spoerri A, Zwahlen M, Gutzwiller F, Paccaud F, Braun-Fahrlander C, Rougemont A, Egger M. Cohort Profile: the Swiss National Cohort--a longitudinal study of 6.8 million people. Int J Epidemiol 2009: 38(2): 379-384.

6. West EA, Strassmann A, Wang C, Turk A, de Hoogh K, Röösli M, Bopp M, Buist AS, Dressel H, Puhan MA. Increase in Airway Obstruction between 1993 and 2012 in Switzerland. An Observational Study. Annals of the American Thoracic Society 2020: 17(4): 457-465.

7. Strassmann A, Kaufmann M, Dressel H, Turk A, Röösli M, de Hoogh K, Sadhra SS, Bopp M, Puhan MA. Occupational exposure and the risk of airway obstruction and mortality. International journal of public health 2020.

8. Wang C, Puhan MA, Furrer R. Generalized spatial fusion model framework for joint analysis of point and areal data. Spatial Statistics 2018: 23: 72-90.

9. Singer F, Stern G, Thamrin C, Fuchs O, Riedel T, Gustafsson P, Frey U, Latzin P. Tidal volume single breath washout of two tracer gases--a practical and promising lung function test. PloS one 2011: 6(3): e17588.

10. de Hoogh K, Saucy A, Shtein A, Schwartz J, West EA, Strassmann A, Puhan M, Roosli M, Stafoggia M, Kloog I. Predicting Fine-Scale Daily NO2 for 2005-2016 Incorporating OMI Satellite Data Across Switzerland. Environ Sci Technol 2019: 53(17): 10279-10287.

11. de Hoogh K, Heritier H, Stafoggia M, Kunzli N, Kloog I. Modelling daily PM2.5 concentrations at high spatio-temporal resolution across Switzerland. Environmental pollution (Barking, Essex : 1987) 2018: 233: 1147-1154.

12. Singer F, Stern G, Thamrin C, Abbas C, Casaulta C, Frey U, Latzin P. A new double-tracer gas single-breath washout to assess early cystic fibrosis lung disease. Eur Respir J 2013: 41(2): 339-345.

13. Araya-Cloutier C, Vincken J, Van De Schans M, Hageman J, Schaftenaar G, Den Besten H, al. e. ATS/ERS recommendations for standardized procedures for the online and offline measurement of exhaled lower respiratory nitric oxide and nasal nitric oxide, 2005. Am J Respir Crit Care Med 2005: 171(8): 912-930.

14. EUROSTAT. Verstädterungsgrad (DEGURBA, Degree of Urbanisation). [cited 202005 May]; Available from: http://ec.europa.eu/eurostat/de/web/degree-of-urbanisation/overview 
Table S1: Characteristics of schools in the canton of Zurich and visited by the LuftiBus in the school study (LUIS) at baseline and at one-year follow-up, by degree of urbanisation.

\begin{tabular}{|c|c|c|c|c|c|c|c|}
\hline \multirow{2}{*}{ Schools in canton of Zurich } & \multicolumn{6}{|c|}{ Urbanisation degree } & \multirow[t]{2}{*}{ Total } \\
\hline & \multicolumn{2}{|c|}{ Large urban } & \multicolumn{2}{|c|}{ Small urban } & \multicolumn{2}{|c|}{ Rural } & \\
\hline Number of schools: $\mathrm{n}(\%)$ & 201 & (41) & 228 & (47) & 61 & (12) & 490 \\
\hline Number of classes: $\mathrm{n}(\%)$ & 2450 & (45) & 2602 & (48) & 381 & (7) & 5433 \\
\hline Number of students: $\mathrm{n}(\%)$ & 48718 & $(45)$ & 51588 & $(48)$ & 7333 & (7) & 107639 \\
\hline Average number of students per class & 19.9 & & 19.8 & & 19.2 & & 19.8 \\
\hline \multicolumn{8}{|l|}{ Schools visited by LUIS, baseline } \\
\hline Number of schools: $\mathrm{n}(\%)$ & 15 & $(40)$ & 18 & (49) & 4 & (11) & 37 \\
\hline Number of classes: $\mathrm{n}(\%)$ & 149 & (39) & 204 & $(54)$ & 26 & (7) & 379 \\
\hline Number of students: $\mathrm{n}(\%)$ & 2959 & (40) & 3842 & (53) & 536 & (7) & 7337 \\
\hline Average number of students per class & 19.9 & & 18.8 & & 20.6 & & 19.4 \\
\hline \multicolumn{8}{|l|}{ Schools visited by LUIS, follow-up } \\
\hline Number of schools: $n$ (\%) & 4 & $(21)$ & 13 & $(68)$ & 2 & $(11)$ & 19 \\
\hline Number of classes: $\mathrm{n}(\%)$ & 45 & $(23)$ & 143 & (73) & 7 & (4) & 195 \\
\hline Number of students: $\mathrm{n}(\%)$ & 917 & (24) & 2679 & $(72)$ & 143 & (4) & 3739 \\
\hline Average number of students per class & 20.4 & & 18.7 & & 20.4 & & 19.2 \\
\hline
\end{tabular}

Calculations are based on aggregated data provided by the Swiss federal statistical office. The number of schools in the canton of Zurich corresponds to the year 2013. Definition of urbanization degree [14]: Large urban area: At least $50 \%$ lives in highdensity clusters. Small urban area: Less than $50 \%$ of the population lives in rural grid cells and less than $50 \%$ lives in a highdensity cluster. Rural area: More than $50 \%$ of the population lives in rural grid cells. 
Table S2: Number of participants in the LuftiBus in the school (LUIS) study with available information on parental questionnaires (PQ), children's questionnaires (CQ), spirometry (Spiro), and fractional exhaled nitric oxide (FeNO) at baseline and at the one-year follow-up.

\begin{tabular}{|c|c|c|c|c|c|c|c|c|}
\hline \multicolumn{5}{|c|}{ Available data } & \multicolumn{2}{|c|}{$\begin{array}{l}\text { Baseline } \\
\mathrm{N}=3870\end{array}$} & \multicolumn{2}{|c|}{$\begin{array}{l}\text { Follow-up } \\
N=655\end{array}$} \\
\hline & & & & & $\mathrm{n}$ & (\%) & $\mathrm{n}$ & (\%) \\
\hline$P Q$ & & & & & 3457 & (89) & 629 & (96) \\
\hline $\mathrm{CQ}$ & & & & & 3546 & (92) & 640 & (98) \\
\hline Spiro & & & & & 3446 & (89) & 614 & (94) \\
\hline FeNO & & & & & 3393 & (88) & 588 & (90) \\
\hline DTG-SBW & & & & & 1795 & (46) & 496 & (76) \\
\hline$P Q$ & $\& C Q$ & & & & 3171 & (82) & 614 & (94) \\
\hline$P Q$ & \& Spiro & & & & 3071 & (79) & 589 & (90) \\
\hline$P Q$ & \& FeNO & & & & 3030 & (78) & 565 & (86) \\
\hline$P Q$ & \& DTG-SBW & & & & 1627 & (42) & 472 & (72) \\
\hline $\mathrm{CQ}$ & \& Spiro & & & & 3230 & (83) & 610 & (93) \\
\hline $\mathrm{CQ}$ & \& FeNO & & & & 3183 & (82) & 584 & (89) \\
\hline $\mathrm{CQ}$ & \& DTG-SBW & & & & 1784 & (46) & 492 & (75) \\
\hline Spiro & \& FeNO & & & & 3165 & (82) & 561 & (86) \\
\hline Spiro & \& DTG-SBW & & & & 1585 & (41) & 472 & (72) \\
\hline FeNO & \& DTG-SBW & & & & 1595 & (41) & 451 & (69) \\
\hline $\mathrm{CQ}$ & \& Spiro & \& FeNO & & & 2964 & (77) & 557 & (85) \\
\hline $\mathrm{CQ}$ & \& Spiro & \& DTG-SBW & & & 1579 & (41) & 469 & (72) \\
\hline $\mathrm{CQ}$ & \& FeNO & \& DTG-SBW & & & 1585 & (41) & 448 & (68) \\
\hline$P Q$ & \& Spiro & \& FeNO & & & 2824 & (73) & 539 & (82) \\
\hline$P Q$ & \& Spiro & \& DTG-SBW & & & 1429 & (37) & 449 & (69) \\
\hline$P Q$ & $\& C Q$ & \& Spiro & & & 2882 & (74) & 585 & (89) \\
\hline$P Q$ & $\& C Q$ & \& FeNO & & & 2845 & (74) & 561 & (86) \\
\hline$P Q$ & \& FeNO & \& DTG-SBW & & & 1429 & (37) & 429 & (65) \\
\hline Spiro & \& FeNO & \& DTG-SBW & & & 1460 & (38) & 430 & (66) \\
\hline$P Q$ & $\& C Q$ & \& Spiro & \& FeNO & & 2646 & (68) & 535 & (82) \\
\hline$P Q$ & $\& C Q$ & \& FeNO & \& DTG-SBW & & 1421 & (37) & 426 & (65) \\
\hline$P Q$ & \& Spiro & \& FeNO & \& DTG-SBW & & 1305 & (34) & 409 & (62) \\
\hline$P Q$ & $\& C Q$ & \& FeNO & \& DTG-SBW & & 1421 & (37) & 426 & (65) \\
\hline $\mathrm{CQ}$ & \& Spiro & \& FeNO & \& DTG-SBW & & 1454 & (38) & 427 & (65) \\
\hline$P Q$ & $\& C Q$ & \& Spiro & \& FeNO & \& DTG-SBW & 1300 & (34) & 406 & (62) \\
\hline
\end{tabular}

Number of measurements before quality control. 


\section{Asthma Medikamente}

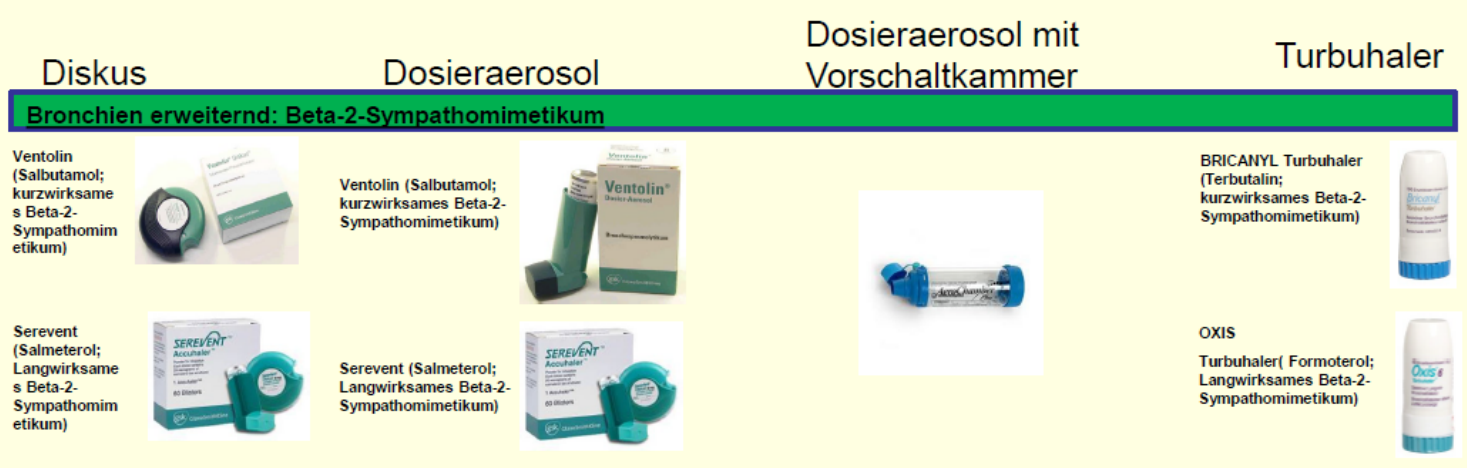

Antientzündlich - Inhalative Kortikosteroide

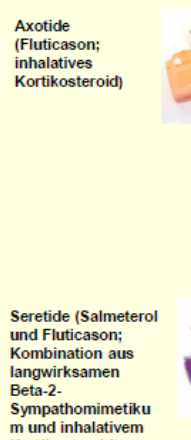

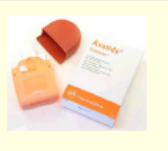

Axotide
(Fluticason;
inhalatives
Kortikosteroid)

Pulmicort (Budesonid;

inhalatives
Kortikosteroid)

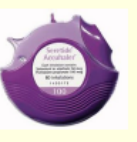

Seretide (Salmeterol und

Fluticason; Kombination
aus langwirksamen Beta-

2-Sympathomimetikum

und inhalativem
Kortikosteroid)

m und inhalativem

Kortikosteroid]
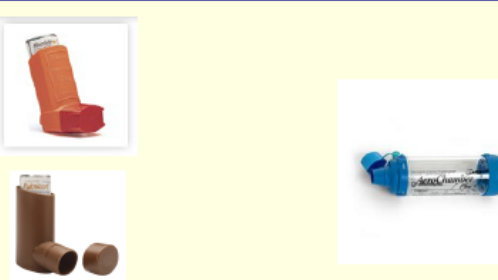

Leukotrienrezeptor-Antagonisten Singulair (Montelukast;

Symbicort (Formotero

und Budesonid; ;

Kombination aus
langwirksamen Beta-2

langwirksamen Beta-2-
Sympathomimetikum und

Kortikosteroid)

Pulmicort (Budesonid;

inhalatives

Kortikosteroid

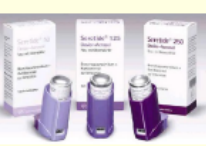

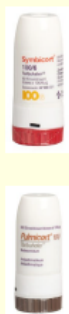

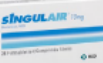

Figure S1: Poster of asthma medications used in the LuftiBus in the school (LUIS) study to help children answer which medication they had taken the day of the visit (in German). 

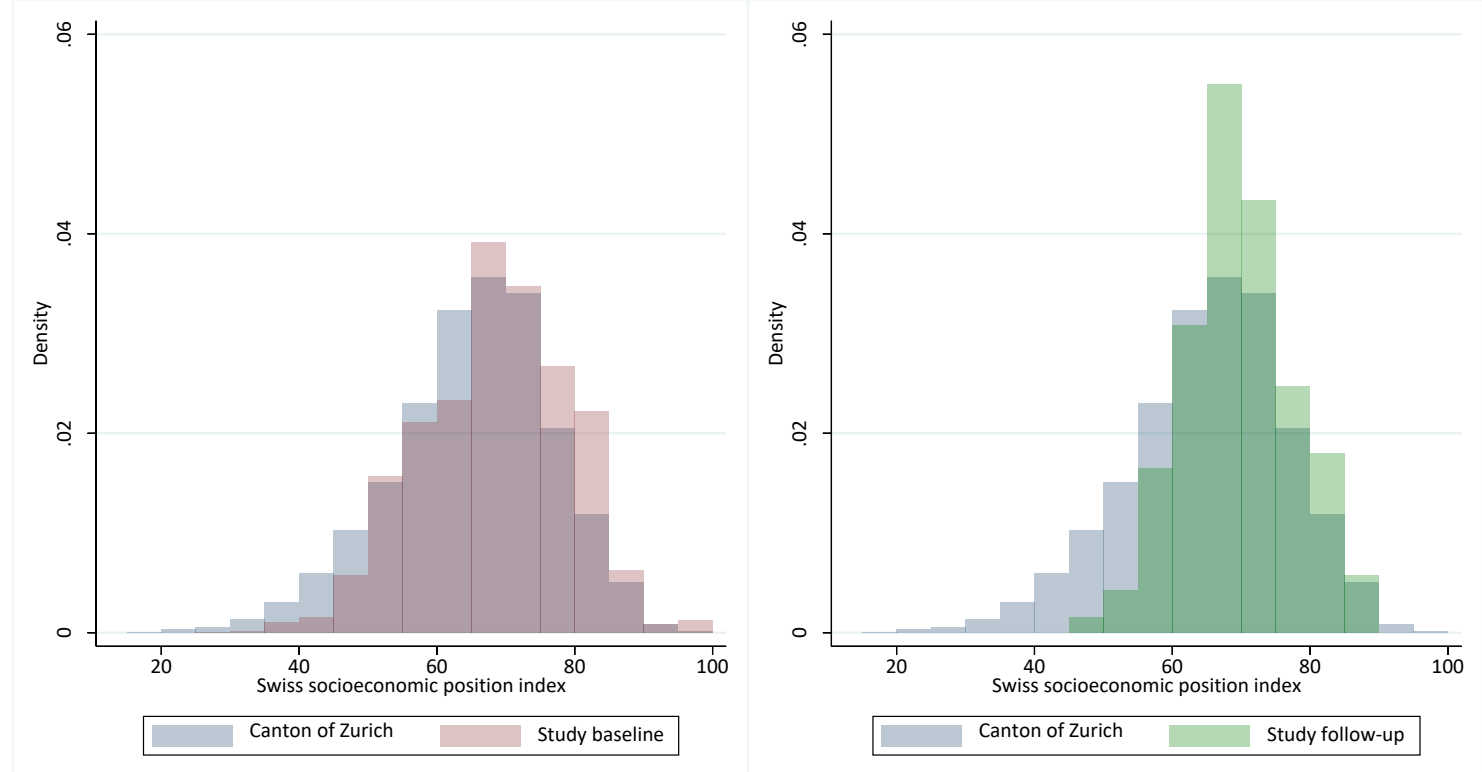

Figure S2: Histograms showing the distribution of the Swiss socioeconomic position index for families from the canton of Zurich with at least one child aged 6-17 years living in the household and in the LuftiBus in the school (LUIS) study at baseline and one-year follow-up. 


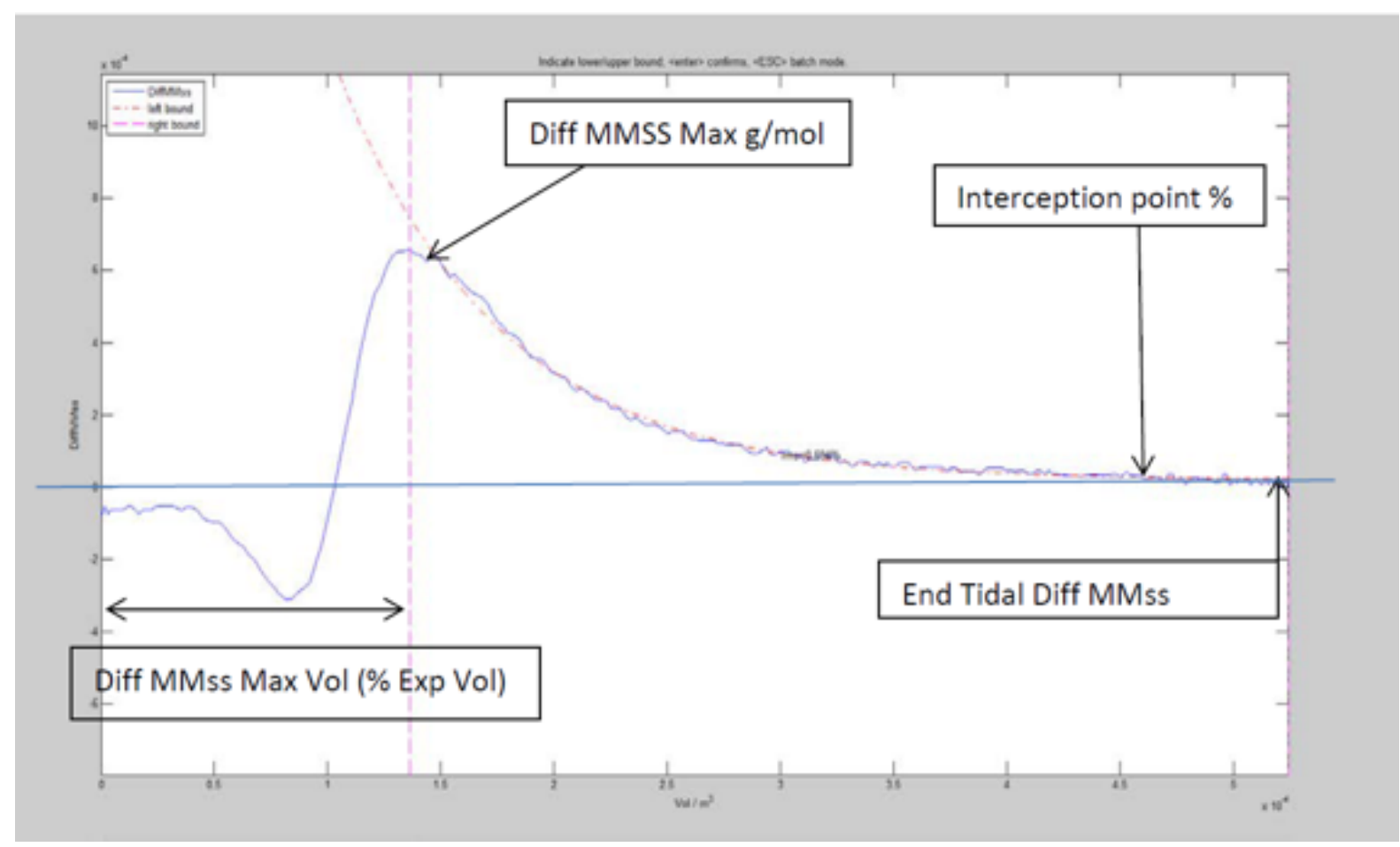

Figure S3: Fit lines of double tracer gas single breath washout (DTG-SBW), differences in molar mass (MM) plotted against expired volume.

Abbreviations: MMss $=$ Molar mass signal of the side stream; MMss calc $=$ Calculated molar mass signal of the side stream using measured gas proportion of a normal breath; Diff MMss = MMss - MMss calc; End Tidal Diff MMss: Difference of MMss - MMss calc (in \%) at the end of expiration; Interception point (\%): \% of expired volume where Diff MMss = 0; Diff MMss Max Vol (\% Exp Vol): Difference of MMss-MMss calc at the maximum expired volume; Left and right bound $=65-95 \%$ of expired volume. 